УДК 351.84

DOI: https://doi.org/10.37320/2415-3583/10.19

Парубець О.М.

доктор економічних наук, доцент,

Чернігівський національний технологічний університет ORCID: http://orcid.org/0000-0001-5357-7581

Сугоняко Д.О.

кандидат економічних наук, доцент,

Чернігівський національний технологічний університет ORCID: http://orcid.org/0000-0002-5054-7253

\title{
КОНЦЕПЦІЯ РОЗВИТКУ СИСТЕМИ СОЦІАЛЬНОГО ЗАХИСТУ НАСЕЛЕННЯ В УМОВАХ ІНФОРМАТИЗАЦІї ЕКОНОМІКИ ТА СУСПІЛЬСТВА
}

Глобальні модернізаційні процеси, щзо відбуваються в економіці й суспільстві під впливом розвитку інформаційно-комунікаційних технологій, потребують розроблення нових підходів до функціонування і розвитку системи соиіального захисту населення. Недостатній рівень інформаційної взаємодії між органами державної влади, місиевого самоврядування, інститутами соиіального захисту громадян та населенням призводить до невідповідності якості соиіальних послуг міжнародним стандартам. Формування єдиного інформаційного простору дасть змогу підвищити рівень обізнаності стосовно програм соціального захисту та забезпечити рівну доступність населення до сочіальних послуг, незважаючи на місие їх проживання $і$ вік. У статті виявлено проблеми в системі соиіального захисту населення, пов'язані з відсутністю розвиненої інформаційної інфраструктури надання соиіальних послуг населенню. Розроблено стратегію розвитку системи соиіального захисту населення Украӥни в умовах розвитку інформаційної економіки й обтрунтовано мету і пріоритети ї̈ реалізації, вектори, індикатори та засоби реалізації.

Ключові слова: сочіальний захист, стратегія, інформатизаџія, розвиток, якість.

Постановка проблеми. Система соціального захисту базується на наданні широкого спектру соціальних послуг для забезпечення поліпшення якості і рівня життя населення. Диспропорції між попитом і пропозицією на ринку праці, низький рівень оплати праці, незадовільні умови роботи і відпочинку працюючих, відсутність системи обов'язкового медичного страхування, проблеми в системі пенсійного забезпечення, недієвість програм соціальної підтримки молодих сімей зумовлюють виникнення системних проблем у системі соціального захисту населення України та потребують розроблення дієвих заходів щодо їх вирішення, особливо в умовах глобальної інформатизації економіки. Накопичені системні проблеми в системі соціального захисту ускладнюються відсутністю розвиненої інформаційної інфраструктури надання соціальних послуг. У таких умовах забезпечити відповідність якості зазначених послуг міжнародним i національним стандартам без упровадження сучасних інформаційних технологій дуже важко. Відсутність обміну інформацією між споживачами соціальних послуг, фондами соціального страхування, органами державної влади та місцевого самоврядування стосовно надання різних видів соціальної допомоги викликає необхідність розроблення нових концептуальних підходів до розвитку системи соціального захисту населення в Україні, чим і зумовлюється актуальність даного дослідження.
Аналіз останніх досліджень i публікацій. Теоретико-практичному обгрунтуванню проблем та дослідженню перспектив розвитку системи соціального захисту населення присвячено праці провідних учених, зокрема Н.А. Балтачеєвої [1], В.В. Лаврухіна [2], М.І. Мальованого [2], Ю.О. Махортова [3], К.В. Павлюка [4], О.В. Степанової [4], Н.А. Телічко [3] та багатьох інших.

Переважну кількість наукових праць присвячено обгрунтуванню напрямів модернізації та стратегій розвитку системи соціального захисту населення, що спрямовані на трансформацію діяльності інститутів обов'язкового соціального страхування, збільшення джерел фінансування такої системи за рахунок залучення приватних коштів, удосконалення моніторингу і системи управління соціальними ризиками, приведення якості соціальних послуг до міжнародних стандартів тощо. Однак в умовах розвитку інформаційних технологій відставання від їх упровадження в систему соціального захисту населення може призвести до загострення існуючих проблем. У зв'язку із цим необхідне проведення подальших досліджень питання розвитку відкритості і доступності соціальної інформації для широких верств населення, що потребують соціальної допомоги.

Мета статті полягає у дослідженні проблем у системі соціального захисту, розробленні та обгрунтуванні концепції іiі розвитку в умовах глобальної інформатизації економіки та суспільства для 
підвищення рівня соціальних стандартів та зростання соціально-економічного розвитку України.

Для досягнення поставленої мети необхідно:

- провести аналіз вітчизняного i зарубіжного досвіду функціонування систем соціального захисту населення;

- виявити проблеми становлення та розвитку вітчизняної системи соціального захисту населення;

- узагальнити науково-теоретичні підходи до сутності та механізмів державного регулювання зазначеної системи;

- сформувати рекомендації стосовно розроблення концепції розвитку вітчизняної системи соціального захисту населення в умовах інформатизації економіки та суспільства.

Основні принципи дослідження:

- комплексності, згідно 3 яким досліджується державне регулювання системи соціального захисту під час розгляду його взаємозв'язку та взаємодії з іншими процесами і явищами, що відбуваються в державі й суспільстві;

- взаємозв'язку із зовнішнім середовищем, відповідно до якого державне регулювання системи соціального захисту населення має динамічно змінюватися й удосконалюватися адекватно до змін, що відбуваються у зовнішньому середовищі під впливом процесів глобалізації та інформатизації;

- цілісності, за яким досліджуються окремі складові елементи системи соціального захисту населення, органічно інтегровані в єдину систему;

- структурності, який обгрунтовує закономірність зв'язку між складовими частинами системи соціального захисту, що забезпечує іiі єдність, пояснює особливість іiі внутрішньої будови;

- системності - дає змогу визначити напрями вдосконалення системи соціального захисту населення та механізму їі державного регулювання.

У ході дослідження використано такі методи: аналізу і синтезу - під час вивчення основних законодавчо-нормативних актів щодо регулювання системи соціального захисту населення в Україні; індукції і дедукції - для формулювання обгрунтованих висновків на основі результатів дослідження; логічний - під час вибору механізмів, інструментів, підходів, які впливають на результативність зазначеної системи; статистичний - для проведення аналізу показників соціального захисту населення у вітчизняній та зарубіжній практиці; наукового обгрунтування - під час розроблення рекомендацій стосовно вдоскона- лення механізму державного регулювання системи соціального захисту населення з метою підвищення ефективності іiі функціонування.

Виклад основного матеріалу. Соціальний захист включає соціальне забезпечення, а також охоплює гарантії охорони здоров'я, праці, природного середовища, мінімальної оплати праці, забезпечення нормального рівня життєдіяльності людини.

Основним гарантом економічного забезпечення соціально придатного рівня життя вразливим i малозабезпеченим рівням населення виступає держава, яка розробляє і реалізує заходи соціального захисту; здійснює регулювання діяльності органів соціального захисту населення шляхом прийняття відповідних нормативно-правових актів; забезпечує мінімальний рівень соціальних гарантій і розробляє стратегічні і тактичні напрями соціальної політики; організовує роботу та здійснює контроль над діяльністю небюджетних державних фондів соціального страхування та виконанням ними вимог законодавства.

Поряд iз державними органами, стейкхолдерами, на рівні яких реалізуються заходи і програми соціального захисту населення України, виступають також органи місцевої влади і самоврядування, які забезпечують організацію надання якісних соціальних послуг на рівні територіальних громад, а також соціально відповідальні бізнес-структури. Останні забезпечують підтримку другого рівня пенсійного страхування в Україні, інвестують кошти у вирішення соціальних проблем та створюють за рахунок чистого прибутку фондів соціального розвитку для працівників підприємств.

У кожній країні світу, виходячи зі стану їі соціально-економічного розвитку, розробляється такий стандарт, як мінімальний рівень соціального захисту, що складається 3 набору визначених країною базових державних гарантій, які повинні забезпечувати доступ до основних життєво важливих соціальних послуг і гарантувати мінімальний дохід.

Одним із показників, за яким можливо оцінити ступінь соціальної відповідальності держави, $\epsilon$ відношення державних витрат на соціальний захист населення, у відсотках до ВВП (табл. 1).

Підписання Угоди про асоціацію між Україною та Свропейським Союзом зумовлює необхідність приведення законодавства у сфері соціального захисту населення до європейських вимог і стандартів, а також порівняння рівня державних витрат на соціальний захист. За даними Свростату,

Державні витрати на соціальний захист населення України, \% до ВВП

Таблиця 1

\begin{tabular}{|c|c|c|c|c|c|}
\hline \multirow{2}{*}{ Показник } & \multicolumn{5}{|c|}{ Роки } \\
\cline { 2 - 7 } & $\mathbf{2 0 1 4}$ & $\mathbf{2 0 1 5}$ & $\mathbf{2 0 1 6}$ & $\mathbf{2 0 1 7}$ & $\mathbf{2 0 1 8}$ \\
\hline Витрати на соціальний захист населення & 8,7 & 8,9 & 10,8 & 9,6 & 8,7 \\
\hline
\end{tabular}

Джерело: складено авторами на основі [6] 
у 2016 р. витрати на соціальний захист населення в країнах ЄС становили в середньому 28,2\% від ВВП. Найбільший обсяг витрат мали такі країни EC, як Франція - 34,3\%, Фінляндія - 32\%, Данія $31,6 \%$ від ВВП. Найнижчий рівень зазначених витрат спостерігався у Латвї - 15,2\%, Литві 15,4\% та Румунії - 14,6\% від ВВП [7].

Порівнюючи рівень державних витрат на соціальний захист населення України і країн СС у відсотках до ВВП, спостерігається значний розрив, що свідчить про існування системних проблем у сфері соціального захисту населення та механізмі іiі державного регулювання. Структура та складові елементи механізму державного регулювання системи соціального захисту України наведено на рис. 1.

Дослідження складників вищезазначеного механізму дає змогу виділити основні проблеми в системі соціального захисту населення та запропонувати напрями їх усунення (табл. 2).
Одними 3 основних проблем функціонування системи соціального захисту населення $є$ недостатній рівень інформаційної взаємодії інститутів соціальної сфери, органів державної влади та місцевого самоврядування, а також низький рівень розвитку інформаційно-комунікаційних технологій на рівні сіл і селищ, окремих об'єднаних територіальних громад. У Стратегіï реформування системи надання соціальних послуг зазначено, що така система не є ефективною з причині відсутності обміну інформацією стосовно надання різних видів соціальної допомоги, законодавчих актів у сфері чіткого визначення повноважень органів виконавчої влади та місцевого самоврядування в напрямі забезпечення розвитку системи надання соціальних послуг, розвиненої інфраструктури та конкурентоспроможного ринку соціальних послуг [8].

Програми соціального захисту населення переважно реалізуються органами державної

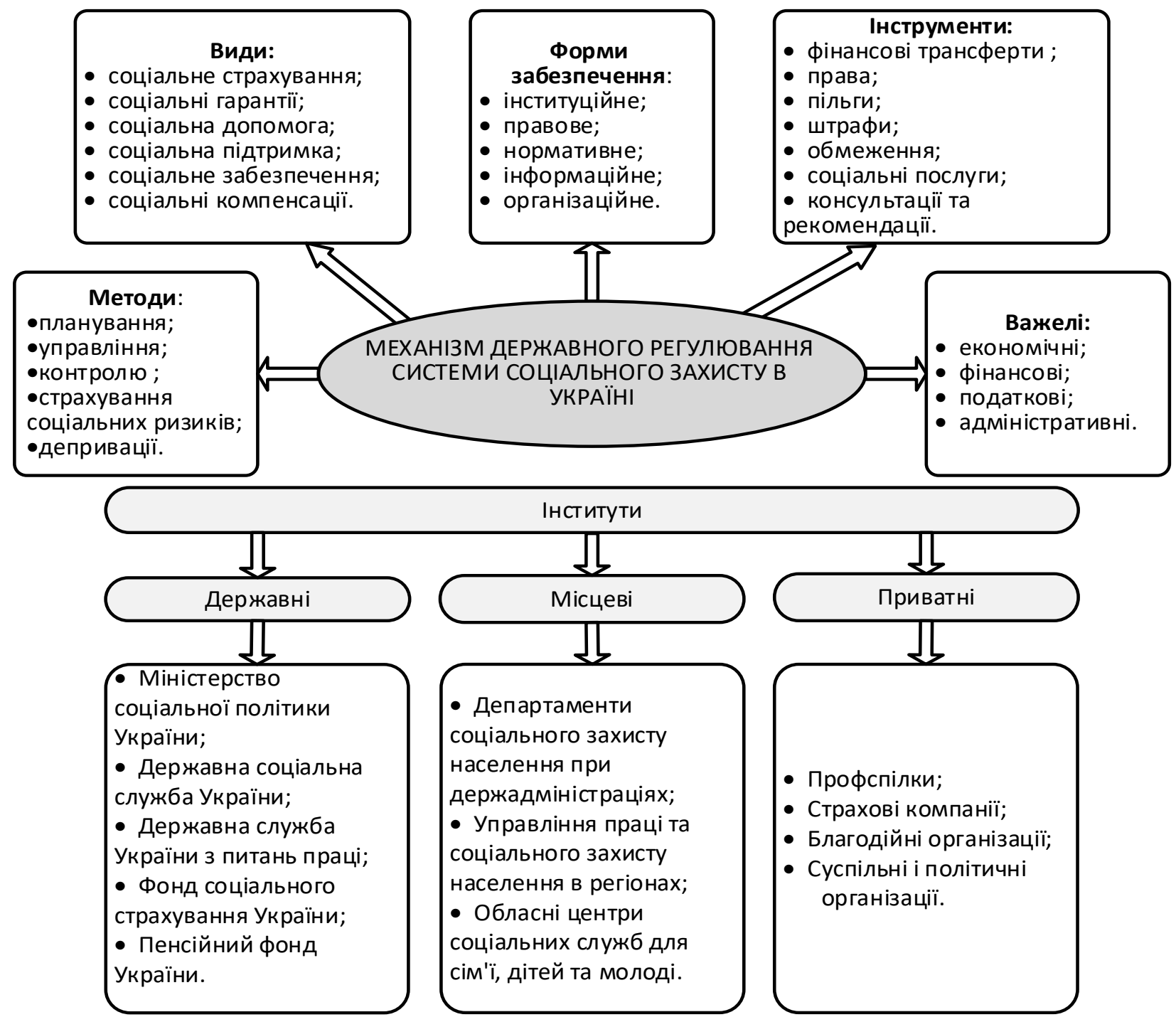

Рис. 1. Механізм державного регулювання системи соціального захисту України 
Таблиця 2

Проблеми в системі соціального захисту населення України та напрями їх вирішення

\begin{tabular}{|c|c|}
\hline Проблеми & Напрямки вирішення \\
\hline $\begin{array}{l}\text { Незадоволення молоді і осіб працездат- } \\
\text { ного віку своїм матеріальним станови- } \\
\text { щем та умовами праці, низький рівень } \\
\text { обізнаності з питань соціального захисту } \\
\text { та забезпечення прав робітників }\end{array}$ & $\begin{array}{l}\text { Усунення конфлікту інтересів між пріоритетами економічного розвитку } \\
\text { і принципами соціальної справедливості, надання державних гарантій } \\
\text { забезпечення якісного рівня життя тим, хто не може досягти цього само- } \\
\text { стійно, запровадження системи обов'язкового медичного страхування, } \\
\text { посилення державного контролю над діяльністю недержавних пенсійних } \\
\text { фондів, трансляція засобами масової інформації соціальної реклами, яка } \\
\text { повинна включати правові та економічні аспекти захисту прав працю- } \\
\text { ючих, програми допомоги в працевлаштуванні; проведення навчально- } \\
\text { просвітницьких заходів із питань соціального захисту населення. }\end{array}$ \\
\hline $\begin{array}{l}\text { Обмеженість можливостей бюджет- } \\
\text { ного фінансування соціального захисту } \\
\text { населення }\end{array}$ & $\begin{array}{l}\text { Упровадження ринкових важелів соціального захисту під контролем } \\
\text { iз боку держави, розвиток інформаційно-комунікаційних технологій, } \\
\text { державно-приватного партнерства для реалізації соціальних програм } \\
\text { та поліпшення якості соціальних послуг. }\end{array}$ \\
\hline $\begin{array}{l}\text { Видатки на соціальний захист визнача- } \\
\text { ються відповідно до кількості громадян } \\
\text { iз доходами нижче за встановлений про- } \\
\text { житковий мінімум }\end{array}$ & $\begin{array}{l}\text { Планування видатків бюджету на соціальний захист повинно врахо- } \\
\text { вувати кількість осіб, рівень споживання продовольчих і непродо- } \\
\text { вольчих товарів та послуг якими є нижчим за розмір фактичного про- } \\
\text { житкового мінімуму й є недостатнім для підтримки якісного способу } \\
\text { життя, що склалося у суспільстві. }\end{array}$ \\
\hline $\begin{array}{l}\text { Встановлення прожиткового мінімуму } \\
\text { базується на можливостях видаткової час- } \\
\text { тини державного бюджету і прив'язується } \\
\text { до розміру споживчого кошика }\end{array}$ & $\begin{array}{l}\text { ого мінімуму повинен установлюватися виходячи } 3 \\
\text { оціально-економічного розвитку держави }\end{array}$ \\
\hline $\begin{array}{l}\text { Скорочення ВВП призводить до змен- } \\
\text { шення заробітної плати найманих пра- } \\
\text { цівників і провокує зростання рівня бід- } \\
\text { ності серед працездатного населення }\end{array}$ & $\begin{array}{l}\text { Перехід економіки на інноваційно-інвестиційну модель розвитку, чітке } \\
\text { визначення ролі держави у забезпеченні фінансового благополуччя } \\
\text { громадян, підвищення рівня соціальної безпеки громадян завдяки } \\
\text { впровадженню ефективної системи управління соціальними ризиками, } \\
\text { забезпечення соціально-економічних прав працездатних громадян }\end{array}$ \\
\hline
\end{tabular}

Джерело: складено авторами

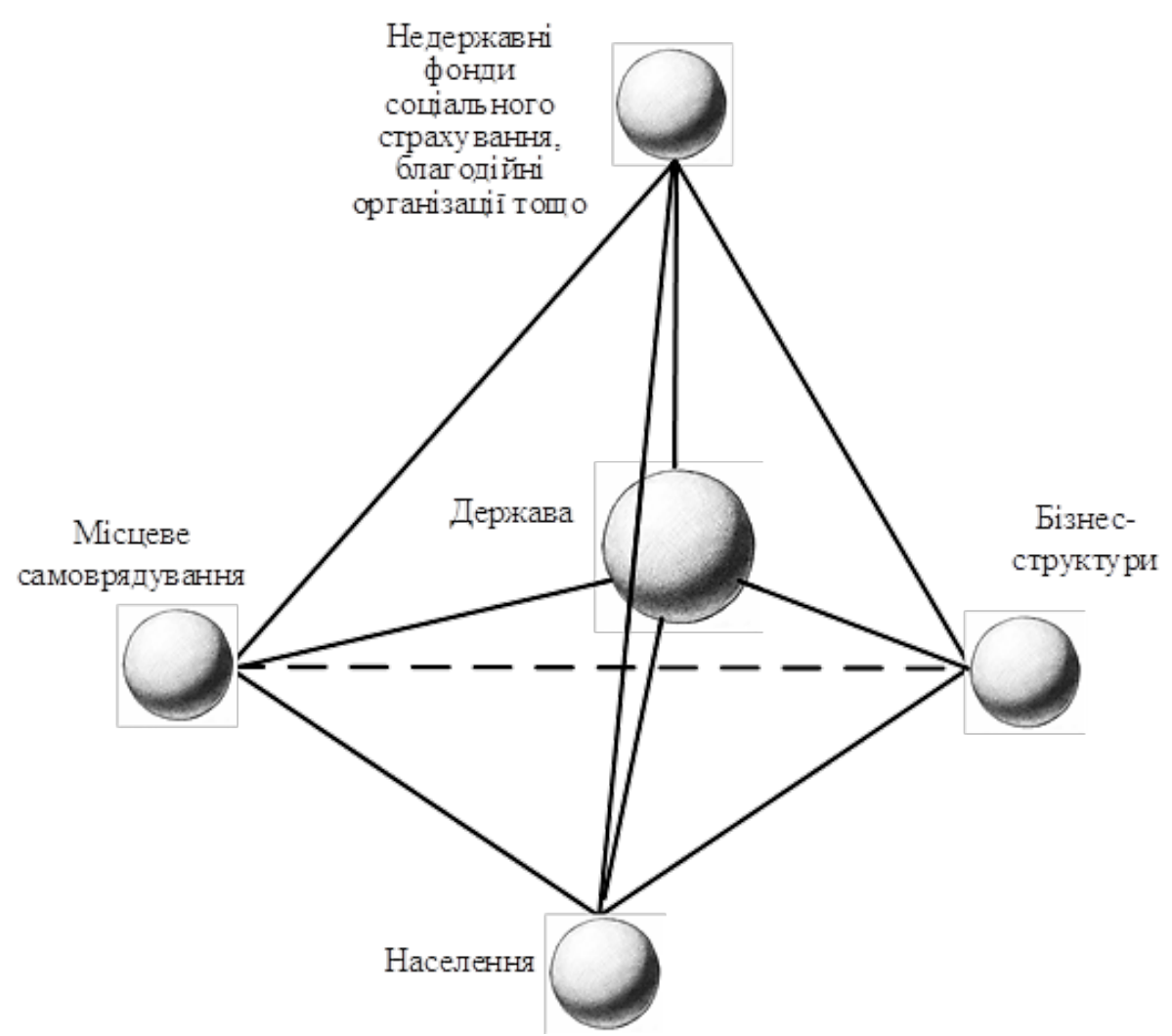

Рис. 2. Єдиний інформаційний простір розвитку соціального партнерства в Україні 
влади й управління за рахунок коштів державного i місцевих бюджетів, кошти яких є обмеженими. В умовах побудови інформаційного суспільства необхідне розроблення ефективної соціальної політики, головні напрями якої в сучасних умовах повинні включати розроблення й упровадження законодавчих актів у сфері розвитку соціального підприємництва, підвищення соціальної відповідальності бізнес-структур; активне залучення представників бізнесу до фінансування програм і проєктів соціального захисту, розвиток соціальної інфраструктури; створення фондів соціаль- ного розвитку колективу на рівні підприємств, установ, організацій. Відсутність інформаційної взаємодії між органами державної влади та місцевого самоврядування, бізнес-структурами, інститутами соціальної сфери та населенням призводить до незадоволення якістю соціальних послуг їх споживачами.

Підвищення рівня добробуту громадян України потребує популяризації соціальних проєктів із метою залучення приватних інвесторів, формування нових управлінських компетенцій, навичок, знань, упровадження солідарного соціального

Концепція стратегії розвитку системи соціального захисту населення в Україні

\begin{tabular}{|c|c|c|c|c|}
\hline Мета реалізації & $\begin{array}{c}\text { Пріоритети } \\
\text { реалізації }\end{array}$ & Вектори & $\begin{array}{c}\text { Стратегічні } \\
\text { індикатори } \\
\text { реалізації }\end{array}$ & $\begin{array}{c}\text { Засоби } \\
\text { реалізації }\end{array}$ \\
\hline $\begin{array}{c}\text { Визначення } \\
\text { концептуальних } \\
\text { засад } \\
\text { формування } \\
\text { та реалізації } \\
\text { державної } \\
\text { соціальної } \\
\text { політики з мето } \\
\text { наближення } \\
\text { соціальної } \\
\text { системи захисту } \\
\text { населення до } \\
\text { європейської та } \\
\text { світової } \\
\text { практики }\end{array}$ & $\begin{array}{c}\text { Підвищення } \\
\text { рівня } \\
\text { інформатизації } \\
\text { надання } \\
\text { соціальних } \\
\text { послуг шляхом } \\
\text { впровадження } \\
\text { новітніх } \\
\text { інформаційно- } \\
\text { комунікаційних } \\
\text { технологій }\end{array}$ & 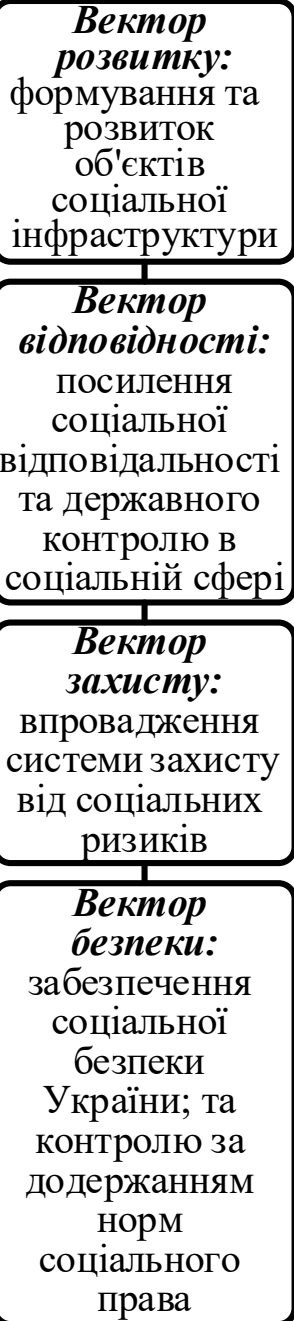 & 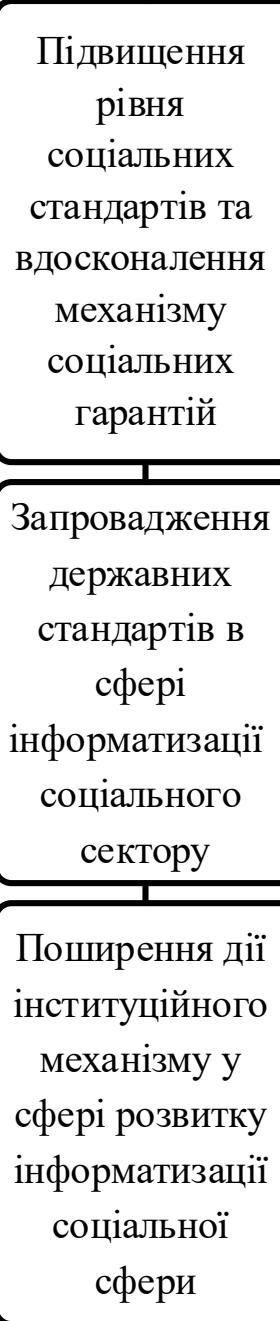 & 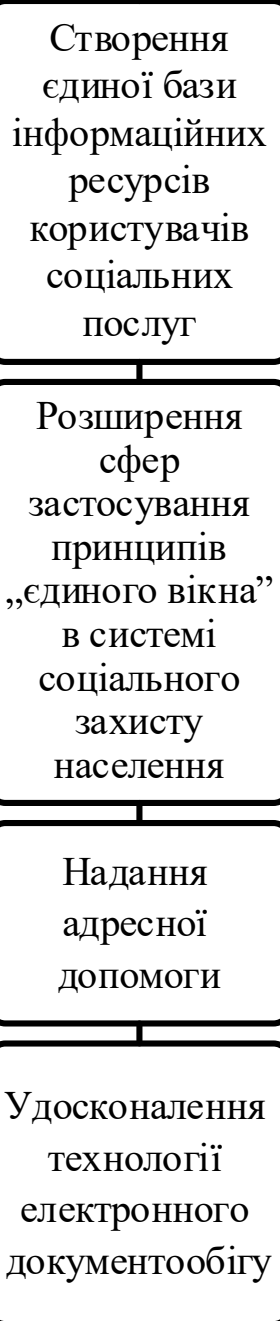 \\
\hline
\end{tabular}

Рис. 3. Концепція стратегії розвитку системи соціального захисту населення України в умовах інформаційної економіки 
забезпечення та розвитку соціального партнерства. Модель побудови соціального партнерства в умовах розвитку інформаційно-комунікаційних технологій наведено на рис. 2.

Розвиток моделі соціального партнерства потребує розроблення відповідної концепції, що дасть змогу забезпечити відкритість і доступність інформаційних ресурсів для їх широкого соціального використання в умовах застосування інформаційно-комунікаційних технологій у системі соціального захисту населення, розбудови електронного урядування, побудови цифрової держави. Складники концепції стратегії розвитку системи соціального захисту населення в Україні в умовах розвитку інформаційної економіки наведено на рис. 3.

Кількість та якість інформаційно-комунікаційних технологій, межі і масштаби їх використання сприяють підвищенню ефективності управління, високому рівню взаємодії суб'єктів системи соціального захисту в напрямі реалізації соціальних проєктів і програм, а також прискоренню трансформації системи соціального захисту та приведенню показників іiі діяльності до міжнародних вимог і стандартів.

Висновки. Входження України до світового інформаційного простору потребує розроблення нормативно-правової бази регулювання й управління процесами інформатизації у соціальній сфері, зокрема в системі соціального захисту населення, яка являє собою сукупність заходів i програм, метою яких є скорочення рівня бідності і незахищеності окремих верств населення.

Розширення сфери застосування сучасних інформаційно-комунікаційних технологій у системі соціального захисту населення дасть змогу розширити види та форми соціальних послуг, підвищити їх якість, поліпшити адресність надання соціальної допомоги, наблизити вітчизняні стандарти соціального захисту до міжнародних вимог, зменшити диспропорції у соціально-економічному розвитку адміністративно-територіальних одиниць, забезпечити однаковий рівень доступу населення до соціальних послуг.

\section{Список використаних джерел:}

1. Балтачеєва Н.А. Стратегія розвитку системи соціального захисту населення в Україні. Економіка промисловості. 2012. № 1-2. C. 302-309.

2. Лаврухін В.В. Чинники розвитку комплексного механізму соціального захисту населення. Аспекти публічного управління. 2015. № 3. С. 57-63. DOI : org/10.15421/151520.

3. Мальований М.І. Фінансові аспекти функціонування системи соціального захисту населення в Україні : монографія. Умань : Сочінський М.М., 2016. 496 с.

4. Махортов Ю.О., Телічко Н.А. Інноваційні підходи до удосконалення системи управління сферою соціального захисту населення. Проблеми інноваційно-інвестиційного розвитку. Серія «Економіка та менеджмент». 2018. № 17. C. 4-14. URL : http://nbuv.gov.ua/UJRN/Piir_2018_17_2 (дата звернення: 22.11.2019).

5. Павлюк К.В., Степанова О.В. Модернізація системи соціального захисту в контексті накопичення соціального капіталу в Україні. Фінанси України. 2012. № 6. С. 15-29.

6. Державна служба статистики України. URL : http://www.ukrstat.gov.ua (дата звернення: 20.11.2019).

7. Eurostat. URL : https://ec.europa.eu/eurostat/home? (дата звернення: 20.11.2019).

8. Про схвалення Стратегії реформування системи надання соціальних послуг : Розпорядження Кабінету Міністрів України від 8 серпня 2012 р. № 556-p. URL : https://zakon.rada.gov.ua/laws/show/556-2012-\%D1\%80 (дата звернення: 21.11.2019).

\section{References:}

1. Baltacheieva, N.A. (2012) Stratehiia rozvytku systemy sotsialnoho zakhystu naselennia v Ukraini [Strategy for the system of social protection of the population in Ukraine]. Economics of Industry, vol. 1-2, pp. 302-309. [in Ukrainian]

2. Lavrukhin, V. (2015) Chynnyky rozvytku kompleksnoho mekhanizmu sotsialnoho zakhystu naselennia. [Factors complex mechanism of social protection]. Public Administration Aspects, vol. 3(3), pp. 57-63. doi.org/10.15421/151520. [in Ukrainian]

3. Malevany, M.I. (2016) Finansovi aspekty funktsionuvannia systemy sotsialnoho zakhystu naselennia v Ukraini: monohrafiia. [Financial aspects of the functioning of the social protection system in Ukraine]. Uman: Vydavets "Sochinskyi M.M.", Ukraine. [in Ukrainian]

4. Mahortov, Yu. \& Telichko N. (2018) Innovatsiini pidkhody do udoskonalennia systemy upravlinnia sferoiu sotsialnoho zakhystu naselennia. [Innovative Approaches to Improving the Management System in the Sphere of Social Protection of the Population]. The Problems of Innovation and Investment-driven Development. Series: Economic Sciences, vol. 17, pp. 4-14. doi.org/10.33813/2224-1213.17.2018.01. [in Ukrainian] (accessed 22 November 2019).

5. Pavlyuk, K.V. and Stepanova, O.V. (2012) Modernizatsiia systemy sotsialnoho zakhystu v konteksti nakopychennia sotsialnoho kapitalu v Ukraini. [Modernization of the social protection system in the context of accumulation of social capital in Ukraine]. Finansy Ukrainy, 6, pp. 15-29. [in Ukrainian]

6. State Statistics Service of Ukraine. (2020) Retrieved from: http://www.ukrstat.gov.ua (accessed 20 November 2019).

7. Eurostat. Retrieved from: https://ec.europa.eu/eurostat/home? (accessed 20 November 2019).

8. On approval of the Strategy for reforming the social services delivery system. (2012). Decree of the Cabinet of Ministers of August 8. No. 556-p. Retrieved from: https://zakon.rada.gov.ua/laws/show/556-2012-\%D1\%80. (accessed 21 November 2019). 
Parubets Olena, Sugonyako Dmytro

Chernihiv National University of Technology

\section{CONCEPT OF THE DEVELOPMENT OF SOCIAL PROTECTION SYSTEM OF POPULATION IN THE CONDITIONS OF INFORMATIZATION OF THE ECONOMY AND SOCIETY}

Execution of the functions and tasks assigned to the state authorities and local government in the context of global informatization of the economy and society requires reforming the existing system of social protection and development of perspective directions. Therefore, the chosen research topic is highly relevant. The purpose of the article is to study the problems in the social protection system, to develop and substantiate the concept of its development in the context of global informatization of the economy and society in order to increase the level of social standards and ensure the socio-economic development of Ukraine. In order to achieve this goal, the main tasks, principles and methods of research have been outlined. Based on the analysis of the current state of the system of social protection of population and theoretical and practical statements of scientific works of leading scientists, it has been identified systemic problems that need to be solved. One of these problems is the lag in the development of information technology in the social sphere due to the lack of a developed information infrastructure for providing social services to population. A considerable number of programs of social protection of population are implemented by public authorities and government at the expense of state and local budgets. Lack of information interaction between these bodies and consumers of social services leads to dissatisfaction with the quality of such services. The article investigates the mechanism of state regulation of the social protection system of Ukraine and reveals the problems of its functioning. The strategy of the development of the system of social protection of population has been developed, its strategic goals, stages of implementation, and sources of financing have been specified. The concept of the development of such a strategy with a clear definition of the purpose and priorities of its vectors, indicators and means of implementation has been substantiated. The necessity of building the model of social partnership development in Ukraine has been reflected. At the end of the article, the conclusions and recommendations for further researches in the direction of increasing the level of informatization of the system of social protection of population in Ukraine have been presented.

Key words: social protection, strategy, informatization, development, quality.

JEL classification: I38, I39. 